\title{
Islamist Political Engagement in the Early Years of Multi-party Politics in Turkey: 1945-60
}

\section{Menderes Çinar \& Ipek Gencel Sezgin}

To cite this article: Menderes Çinar \& Ipek Gencel Sezgin (2013) Islamist Political Engagement in the Early Years of Multi-party Politics in Turkey: 1945-60, Turkish Studies, 14:2, 329-345, DOI: 10.1080/14683849.2013.802921

To link to this article: http://dx.doi.org/10.1080/14683849.2013.802921

\section{Published online: 26 Jun 2013.}

5 Submit your article to this journal $\square$

Џll Article views: 413

Q View related articles ¿ 


\title{
Islamist Political Engagement in the Early Years of Multi-party Politics in Turkey: $1945-60$
}

\author{
MENDERES ÇINAR* \& IPEK GENCEL SEZGIN** \\ *Department of Political Science and International Relations, Başkent University, \\ Ankara, Turkey; **Department of Political Science, Bilkent University, Ankara, Turkey
}

\begin{abstract}
This study examines what has been overlooked by most studies of Islamist activism in the early years of the multi-party politics (1945-60) in Turkey. By examining the formal and informal political institutions, power relations and practices, it reveals that the early Islamists did not remain content with only socio-cultural activities. They effectively and creatively engaged with and within the political field, enjoyed an impact disproportionate to their actual numbers and power, and set the parameters for future Islamist activism. In so doing, they reproduced the Republican orthodoxy while advancing their heterodox claims.
\end{abstract}

Islamist movements have played a critical role in Republican Turkey's political life since the passage to multi-party politics in 1945 . Yet, little is known of the political nature of Islamist mobilization during the early years of multi-party politics. Most studies of Islamism in Turkey adopt a macro-sociological approach that takes the emergence of an Islamist political party in the formal sphere of politics in 1970 as the starting point of Islamist political engagement. When addressing the early years of multi-party politics, this approach, although recognizing the emergence of certain Islamist groups and publications, does not consider their political activism and tends to focus on merely Islamic "cultural activities," explaining them as a natural outcome of the relative loosening of the state's grip on religion. ${ }^{1}$

This study delves into Islamist activism between 1945 and 1960 to bring the political into analyses of this time period. Drawing from social movement theories and Bourdieu's Theory of Practice, it examines formal and informal political institutions, power relations, and the practices of political actors. In so doing, this piece unravels the enabling and constraining factors around Islamist activists' emergence, resource mobilization, and engagement with other political actors that allowed (or disallowed) them to impact the political arena and the state.

Correspondence Address: Menderes Çınar, Department of Political Science and International Relations, Başkent University, Baglıca 06810, Ankara, Turkey. Email: mcinar@baskent.edu.tr

The names of the co-authors are given in alphabetical order. 
In what follows, this essay argues that after the passage to a multi-party regime, the early Islamists did not satisfy themselves with socio-cultural activities. They effectively engaged with and within the political field, mobilizing through and around various publications and the two right-wing political parties, namely the mainstream Democrat Party (DP, Demokrat Parti) and its conservative-nationalist offspring, the Nation Party (NP, Millet Partisi). Second, this study demonstrates that the Islamists sustained their mobilization from 1945 to 1953 by delicately balancing the ideational and practical aspects of their engagement between political orthodoxy and heterodoxy, and between cooperation and contestation. In their conflicts with power holders and the regime, they not only appropriated and reinterpreted the Republican doxa,${ }^{2}$ but also made effective use of the formal institutions. This pattern of political engagement enabled them to have a disproportionate influence on the distribution of state-controlled material and symbolic resources, and set the parameters for future mobilizations.

This contribution develops its argument in four steps. The first section discusses the early Islamist mobilization within the framework of existing opportunities and constraints. This is followed by an analysis of Islamist demobilization from 1953 onwards. In the third section, the ideational and practical elements of the Islamist activism in relation to the political context are revealed. The final section briefly recapitulates the main arguments of the essay and provides an overview of the outcomes of Islamist mobilization. The research is primarily based on a review of the three major nationally distributed Islamist publications of the period (1945-60), the minutes of the Turkish Grand National Assembly (GNA, 1945-60) and DP Parliamentary Group meetings (1950-60), which were mostly closed to the public from 1953 onwards. These written resources are used in conjunction with the data derived from 30 in-depth interviews with various Islamist and non-Islamist actors of the period at the central (Ankara and İstanbul) and peripheral levels (Kayseri, Maraş, and Konya) of the political arena. ${ }^{3}$

\section{The Changing Political Opportunity Structures and Early Islamist Mobilization}

In the wake of the Second World War, the ruling Kemalist elites organized in the Republican People's Party (RPP, Cumhuriyet Halk Partisi), introduced a competitive multi-party regime. This regime inevitably resulted in the loosening of state control over religious life ${ }^{4}$ and the polity, thus changing the political opportunity structure, which refers to relatively durable formal and informal institutions and their perception by political actors as creating incentives for collective action. ${ }^{5}$ The former resulted in the (re)emergence of religious groups and networks that formed a potential pool of constituents and activists for Islamist mobilization; ${ }^{6}$ the latter provided the Islamist elites with formal and informal platforms to engage with and within the political field. Locally, Qur'anic courses proliferated, mosque attendance increased, otherwise illegal traditional brotherhoods (for instance, Nakşibendis and Kadiris) thrived and new religious movements such as the Risale-i Nur Students (RNS) ${ }^{7}$ 
and the Süleymancıs ${ }^{8}$ saw the daylight. Local networks shaped around the scholars of the officially prohibited traditional religious schools, medreses, and newly established associations for building and developing Prayer Leader and Preacher (PLP, Imam Hatip) schools or mosques have also provided the potential participants of the Islamist mobilization.

Several formal and informal constraints prevented Islamist activism from forming a durable political party organization. ${ }^{9}$ Nevertheless, there was significant Islamist engagement in politics through other opportunity structures after 1946. The informal liberalization of the polity and then its partial institutionalization through new laws by 1950 relatively freed the press, associational life, and the political field. Subsequently, Islamist actors were able to publish magazines and newspapers, participate in the activities of such right-wing socio-political associations as the Nationalists' Association of Turkey (NAT, Türkiye Milliyetçiler Derneği), join the DP (the mainstream right-wing party), and finally, forge alliances with conservative-nationalists to establish political parties, among them the relatively successful NP. ${ }^{10}$ Through these mediums Islamists were able to communicate and establish long-lasting relations with each other and recruit a new generation of Islamists on the one hand, and on the other, to spar and cooperate with the power holders to initiate policy change.

\section{Islamist Magazines}

While it is not possible to establish the exact number of Islamist periodicals published from 1945 to $1960,{ }^{11}$ it is not difficult to name the most popular and influential ones. Sebilürreşad, Büyük Doğu, and Serdengeçti, and their respective editors/owners, Eşref Edip (Fergan), Necip Fazıl (Kısakürek), and Osman Yüksel (Serdengeçti) ${ }^{12}$ are still revered in Islamist circles as the pioneers of Islamist activism. These magazines supported Islamist activities within the right-wing political parties and associations and contributed to the countrywide dissemination of Islamist mobilization frames and identity from the late 1940s onwards. They owed their impacts at the national and local levels of politics to the fact that:

(1) They could be read for free in about 80 local branches of the NAT throughout the country. $^{13}$

(2) Their editorials were reprinted time and again in various local Islamist and conservative-nationalist publications such as Ehli Sünnet, İslam Yolu, İslamın Nuru, Fetih, and Hakka Doğru. ${ }^{14}$

(3) Their editors and writers frequently visited Anatolian towns for conferences and seminars (usually organized by the NAT) ${ }^{15}$ and established long-term relations with the local religious networks.

Originally Strat-ı Müstakim (1908-09), Sebilürreşad was the most prominent Islamist magazine of the Second Constitutional period of the Ottoman Empire (190818). During the War of Independence (1919-22), it had supported the Kemalist leadership until they established the secular Republic in 1923. Sebilürreşad was 
shut down, along with all other opponent and/or autonomous bodies following the Kurdish/religious Sheikh Said Rebellion in 1925. Its editor, Eşref Edip, was accused of encouraging and supporting the rebellion and was tried in the extraordinary Independence Tribunals, set up temporarily to punish the alleged rebels and their abettors. He managed to avoid capital punishment and went underground, like other Islamists, only to reintroduce Sebilürreşad in 1948 and publish it regularly until 1966. Büyük Doğu and Serdengeçti first appeared in 1943 and 1947, respectively. They were published irregularly because their relatively young editors, Serdengeçti and Necip Fazıl, did not learn how to sidestep the laws and were frequently prosecuted. Although Büyük Doğu was closed down 13 times until its final issue in $1978,{ }^{16}$ it managed to form a dense Islamist network, thanks particularly to Necip Fazıl's charismatic persona and frequent conferences in Anatolia. ${ }^{17}$ Furthermore, since Serdengeçti sent reprints to provincial booksellers, newspapers stands, and subscribers, this magazine's influence and circulation in Anatolia were more than what its mere 33 issues (published between 1947 and 1960) may suggest.

These three major Islamist periodicals became the hubs of Islamist political engagement and facilitated the formation and mobilization of an Islamist network in Turkey. Their uninhibited opposition to the practices of the single-party era induced Islamist elites from different milieus and communities, including Bediüzzaman Said Nursi, the leader of the RNS, to publish their writings in and support these magazines. There were attempts to unite the newly consolidating local Islamist networks into a formal organization. In 1949, Necip Fazil, together with such prominent Islamist columnists and commentators as Cevat Rifat Atılhan (Sebilürreşad), Abdürrahim Zapsu (Ehli Sünnet), Haluk Nurbaki (Islamin Nuru), and Şükrü Çelikalay (a hero of the War of Independence and an Islamist deputy who had opposed the abolition of the Caliphate in 1924) established the Great East Association (GEA, Büyük Doğu Cemiyeti), which dissolved in May 1951 because of financial difficulties. ${ }^{18}$ The second attempt came in August 1951 in the form of the Islam Democrat Party (IDP, İslam Demokrat Partisi) under the leadership of Atılhan. The IDP was banned in November 1952 on the grounds that its program contravened laws prohibiting the use of religious elements in association names and programs.

At the micro level, the cases of the GEA, Atılhan and the IDP, demonstrate how Islamist activists operating within smaller right-wing political parties and associations and the grassroots networks that were formed around Islamist publications were interconnected. In addition to writing regularly for Sebilürreşad, Atılhan contributed to Büyük Doğu and such smaller publications as Hür Adam (İstanbul) and Büyük Cihad (Samsun). ${ }^{19}$ He was a founder of two of the short-lived right-wing parties $^{20}$ as well as the GEA. The IDP itself relied on the previous networks of the GEA, the two largest right-wing associations of the period (the NAT and the Association for Spreading Knowledge, Illim Yayma Cemiyeti), and the groups that had formed around the local periodicals such as Hür Adam, Büyük Cihad, Yeşil Bursa (Bursa) and Büyük Dava (İzmir), all of which "acted like party publications." 21 


\section{The Right-Wing Political Parties}

Unable to function as a political party, Islamists engaged in formal politics primarily through the DP and the strongest of the smaller right-wing parties, the NP. The DP and the NP were coalitions of various political forces, including liberals, conservative-nationalists, ultranationalists, and Islamists. The DP, established and controlled by former RPP elites, defined itself primarily in anti-tutelary terms and attracted divergent social and economic interests and political forces united in their opposition to the authoritarian RPP. The NP, on the other hand, was established in 1948 by prominent conservative-nationalist figures from the DP, ${ }^{22}$ who, accusing DP elites of being too loyal an opposition, wanted a clearer break from the RPP's stringent secularism.

While many Islamists joined the DP and the NP at the local and national levels, ${ }^{23}$ Islamist publications remained non-committal, even aloof, ${ }^{24}$ until the DP's electoral victory in 1950. As the quashing of the two previous attempts at a multi-party regime was on the grounds of increased "reactionaryism," 25 the Islamist magazines probably feared that their explicit support of the DP before the election could provide a pretext to suppress the new attempt as well. From 1950 to the coup d'état of 1960, however, the Islamists allied with and supported the DP, but without entirely abandoning the NP. There seems to be three interrelated factors that motivated Islamists to work and vote for the DP instead of the NP. First, for Islamists, the elections acted as a "plebiscite" on the RPP and its secular reforms, ${ }^{26}$ dividing the vote between the DP and the NP under the majoritarian electoral system of the time would play into the hands of the RPP. Thus, even Islamist NP members were inclined to vote for the DP. ${ }^{27}$ In fact, Islamists within the NP tried to transform their party into a pressure group that would influence decision-making processes without endangering the DP's incumbency. As the following quote from Sebilürreşad illustrates, Islamist magazines supported this stance:

Yes, the Nation Party should criticize the mistakes of the Democrats. In so doing, however, one should not help the Republicans inadvertently, since the Nation Party did not attain the power to prevent the Republicans from plaguing the nation, should the Democrats be toppled. Consequently, it is in the best interest of the nation that the leaders of the Nation Party confront the Republicans rather than the Democrats. ${ }^{28}$

Second, the Islamists needed to tap into state-controlled material and symbolic resources to sustain their mobilization and increase their political capital as a group and as individuals. The DP government, with its liberal attitude toward religion and its eagerness to establish its patronage over Islamists and the religious networks, would indeed help them to overcome, though incrementally and precariously, the strains that their limited organizational, financial, and symbolic capital created. Third, the formal constraints effectively rendered any collective activity relying on religious signs and symbols subject to criminal charges. The survival of formal 
and informal Islamist institutions therefore depended on the tolerance and goodwill of the government, constructing a vicious circle that compelled Islamist activists to seek the protective patronage of the DP, but rendered them hostages to its will.

For Islamists, the early (1950) measures of the DP in the religious domain were relatively satisfactory. Removing the clause from Article 526 of the Penal Code prohibiting the use of any language other than Turkish in reciting ezan (the call to prayer) and then broadcasting Qur'an recitations on the state radio had won their hearts. The Islamist magazines recognized that although the DP was incapable of initiating "a fundamental reform" that would reflect the "values of the people," ${ }^{29}$ they enthusiastically applauded its accomplishments and declared the new DP-dominated GNA as "the complete and free manifestation of the national will," thus legitimate. ${ }^{30}$ The attitudes and speeches of Islamist DP deputies were also complimentary. For instance, Ömer Bilen declared the end of the "oligarchy" and thanked God for being able to talk about "our religion, religiosity, God and the Prophet with no hesitation under this ... roof." $" 31$

Being able to talk about religion helped Islamists form alliances with conservativenationalist DP members and deploy the NP as leverage in pressurizing the DP government to increase the state's material and symbolic investment in the religious domain. The debate over the status of the Presidency of Religious Affairs (PRA) is revelatory. The NP, in an attempt to attract religious and Islamist constituents into its ranks, argued for the establishment of an independent PRA, which would control the vast resources of the nationalized Pious Foundations and thus rescue it from dependence on the DP's patronage. ${ }^{32}$ However, the NP miscalculated Islamist and DP reactions. Islamists sympathized with the idea of an autonomous PRA only to the extent that it would serve to pressure the DP government to alter the nature and direction of the Kemalist control of religion, which aimed at reducing religion's role in public and societal affairs. In other words, Islamists were not against state control of religion itself, but of its nature under RPP rule. As early as 1949, Eşref Edip of Sebilürreşad had maintained that as long as the state "works for the development and growth of the religion [Islam] ..." the government could continue claiming that it was secular free from "disgrace." 33 Consequently, in order to realize their aim, Islamists not only tried to curb the power of conservative-nationalist leaders within the NP, but also continued to cooperate with the DP as long as it supported and developed existing religious institutions and increased religion's role in public affairs. $^{34}$

As the minutes of a June 1953 DP Parliamentary Group meeting show, the DP elites were worried about the NP's intention to capture "the flag of religion" by propagating the PRA's autonomy. ${ }^{35}$ It is thus not surprising that only a few months later, in January 1954, the DP shut down the NP for encouraging "reactionary" activity. ${ }^{36}$ The opportunity was provided by the resignation of prominent conservative-nationalist leaders from the NP in July 1953 in reaction to the NP General Congress' June refusal to ratify the decision expelling famous Islamist M. Raif Ogan from the party. The resignations in the face of what seemed to be an Islamist takeover were viewed by the DP as an official denunciation, paving the way for the party's closure. ${ }^{37}$ This 
was not only a move to protect the secularist image of the DP in the eyes of the Kemalist establishment; it was also aimed at punishing the Islamists (for reasons discussed below) and their conservative-nationalist political rivals: the DP elites did not want to lose their clients to the NP. ${ }^{38}$

\section{The Islamist Demobilization}

The assassination attempt on November 22, 1952, in Malatya of Ahmet Emin Yalman, editor of the daily Vatan, gave the DP government an opportunity to show its secularist credentials, to fend off charges of tolerating and even encouraging "reactionary" activities and to curb the Islamists' growing autonomy. The government began cracking down on Islamists by declaring the assassination attempt part of a larger plot by the GEA and the IDP targeting famous secularist editors of Cumhuriyet, Dünya, and Ulus. ${ }^{39}$ Consequently, Necip Fazıl was charged and convicted with involvement in the "conspiracy" and his magazine was closed down, Serdengeçti ${ }^{40}$ and the RNS were regularly harassed by security forces, and the NAT was closed in 1953 (followed by the above-discussed closure of the NP). ${ }^{41}$ Moreover, five of the DP's Islamist deputies were expelled. ${ }^{42}$ Prime Minister Adnan Menderes defended this action, asserting, "the DP is not a hotel. We will not allow ... those outsiders [with their distinct] ideas, convictions, and organizations ... to exploit us." ${ }^{, 3}$ Henceforth, the Islamist movement was demobilized until the second half of the 1950s. When Islamists resumed their activities, including within the GNA, ${ }^{44}$ they did so with less intensity and avoided confrontation because of the DP's increasingly authoritarian policies and tendency to repress anyone who dared to criticize the government. ${ }^{45}$

\section{Islamist Engagement between Political Orthodoxy and Heterodoxy}

\section{Ideational Aspects}

Islamist movements, similar to other social movements, initiate and sustain mobilization mostly through ideational elements, which fulfill the important task of providing movement activists with interpretive schemata (collective action and identity frames) to render their actions and experiences meaningful, to draw symbolic boundaries between us and them, and to aggregate their resources to achieve shared goals. ${ }^{46}$ Rather than being preconceived or pre-political resources, ideational elements are products of an interactive process within the political field. As such, they are inevitably political in the sense of being politically dependent and politically aspiring.

The Theory of Practice, which investigates the dynamics in such sociological fields as the political arena, science and literature, aids in recognizing the inseparability of ideational elements from power relations. Ideational products are not solely an outcome of the creativity of rational agents. As communication tools, they are part and parcel of power relations, thus intertwined with the doxa of a specific field. They depend on "the [thus far] accumulated material and symbolic power of the individuals (or institutions)" ${ }^{\prime 47}$ within the field of action, on the one hand, and they serve 
to increase this power on the other. It is through the accumulation of symbolic power, that is increasing the value of a specific symbolic capital that is related to one's status within a field, that one builds up material (economic and social) capital and even achieves a monopoly on ideational production ${ }^{48}$ - hence the politically dependent and aspiring nature of action frames and identity.

It could therefore be suggested that Islamist actors tried to increase the value of a symbolic capital that was already available in the political arena and with which they associated themselves: religion. Their ideational production aimed at augmenting the value of things associated with Islam, or reshuffling the symbolic order of things in "Muslims" favor. Such heterodoxy, however, also entailed a hidden orthodoxy: appropriating the entire doxa of the political field, whose "recognition is implicated by membership in the field itself." ${ }^{49}$ In other words, Islamists, like dominant members of the political field who defended the existing hierarchy of doxic elements, adopted the stakes of the game and tacitly "agree[d] on the objects of dissensus," as these were "constitutive of the field itself." 50

An alla Turca definition and practice of secularism, which involves neither separation of religion from state, nor indifference of state towards religion, was institutionalized in the early years of the Republic, thanks to the consolidation of the Kemalist power structure. The institutionalization of secularism meant that secularism provided the foremost element of the doxa of the political field, alongside Turkish nationalism. The nature of secularism as a doxic element was determined by an ideational framework with regard to the role of religion and the practical task of constructing a nation-state over the remnants of a multi-ethnic, multi-confessional, and multicultural empire, where the primary loyalties were to religious communities, tribes, and brotherhoods. The former, having taken the West as its muse and seen an inherent "incompatibility" between Islamic and Western societies, sought to eliminate Islamic values, laws, and customs for a modernization process along Western lines. ${ }^{51}$ The task of constructing a nation-state, however, compelled the Republican elites to accept Islam as a resource for "imagining" the Turkish nation, since the religious geography of Anatolia and Thrace had become quite homogenously Muslim, especially after the deportation and massacre of the Armenians in late Ottoman Empire and the exchange of populations with Greece in early Republic. Yet, using religion to build national identity would not only contradict the Kemalist frames and vision of the nation based on science and knowledge, but could also

(1) Reinforce communitarian loyalties and thus diminish the loyalty for the nationstate.

(2) Encourage extraterritorial ambitions seeking to unite Muslim countries.

(3) Become an ideational resource for Kurdish nationalist mobilization around the brotherhoods.

(4) Substitute the nation as the principal reference of politics and identity. ${ }^{52}$

The Kemalist elites tried to resolve this problem through a definition and practice of secularism that submitted religion to the service and control of the state. This project 
aimed at shaping "a rational and national Islam, charged with the political task of legitimizing [Kemalist] power, supporting its will to eradicate all non-official [forms of] religiosity (brotherhood, Ottoman, Arabic, popular) in the name of progress, revolution and civilization, ${ }^{, 53}$ relegating religion as a private affair. ${ }^{54}$ Secularism was thus elevated "to a constitutional obligation, conditioning even the citizenship," 55 which, in turn, meant, at least within the political arena, "religion and the religious could exist only in a submitted condition" and the nation, whose Muslimness had been admitted, could exist only if "secular."

It was thus not a coincidence that notwithstanding its "submitted" and "domesticated" status, Islam had paradoxically become, alongside Turkishness, secularism, and progress/modernization, a doxic element. Since the doxa was ultimately tied to "the question of exercising power in the name of the nation," Islam, even if subservient, offered an alternative disposition of power for Islamists. Hence, after the transition to competitive politics, Islam and secularism became the most-disputed subjects of the political arena.

Islamists were heterodox players to the extent that they defined the nation primarily as (Sunni) Muslim and claimed to represent its political will. ${ }^{58}$ Specifically, they offered an alternative version of the founding moment of the Turkish nation-state and questioned the legitimacy of the Republican elites and their reforms. The RPP's single-party regime and secularizing reforms were legitimized on the basis of the claim that the RPP was the organization of the nationalist elite and the War of Independence heroes Atatürk and his successor İnönü. After the transition to the multi-party regime, however, taking their clues from such Islamist figures as Eşref Edip or DP parliamentarian Gazi Yiğitbaşı (who themselves fought in the War of Independence), Islamists argued that the nation had engaged in the War with a spirit founded on "religion and faith" 59 and had not envisioned the secular regime established by the RPP. ${ }^{60}$ Hence, they declared the RPP a usurper and its secular reforms illegitimate. Moreover, they claimed that since throughout the single-party period the RPP was unaccountable for its actions, its reforms could not categorically reflect the will of the nation. ${ }^{61}$ Islamists furthered their argument by offering an alternative vision of progress and decline that refuted the Republican blame of Islam for the backwardness of the nation: the "backwardness" was due to the Westernization policies that had been in place since the nineteenth century, which resulted in loss of identity and authenticity as well as in the moral decay of Muslim society. Islamists maintained that Muslims progressed only when they exclusively adopted the principles of Islam. ${ }^{62}$

Hence, Islamists could not escape from reproducing the national will discourse, despite their efforts to differentiate themselves from the power holders. In fact, it was the reproduction of this orthodoxy that gave them the opportunity to introduce their limited heterodoxy. The acceptance of the nation-state boundaries that were formed following the War of Independence; the juxtaposition of Muslimness primarily with the nation that remained within these borders; the rejection of the objective and observable condition of the nation as a political collectivity composed of diverse citizens and socio-economic, ethnic, cultural, and interest groups; and finally, the call 
for moral development, would become staples of the Islamist movements in Turkey in the years to come.

The association of the nation with Muslimness helped the early Islamists and their future generations to express their particularistic material and moral interests and to associate them with the "best interest" of the nation. The reproduction of orthodoxy, to the extent that Islam was its constitutive element, consolidated Islamists as legitimate players in the political game, forced the other actors to play along, and hence amplified Islamists' demands and influence. The appropriation and reinterpretation of the Islamic element of the doxa forced all political actors to think and comment on religious issues: because the mainstream right-wing parties had already put Islam into use to increase their democratic credibility in the eyes of the electorate and the RPP had established itself as a guardian of the secular system, they needed to introduce and reintroduce versions of Muslimness attributed to the nation to face the Islamist challenge.

Consequently, from a perspective focusing on relations of power and parallel opportunity structures, the goal of Turkish Islamists in the political field did not appear to be one of changing state and society as such but one of transfiguring the hierarchy of symbolic values associated with Islam to increase their political, economic, and social capital and those of the movement. There is no need, then, to attribute hidden plans, or ill-formulated ideologies to the actors to explain the discrepancy between their frames of Islamization of state and society and their careful and consensual relations with the elites. To be sure, capturing the state apparatus would be the ultimate solution, as it would reseal the game in Islamist terms, placing Islam and thus its guardians, in the highest echelon. However, as shall be seen, the symbolic and material gains achieved through political engagement satisfied the actors in a multiplicity of ways, such that the ultimate solution, either implicit or explicit in their symbolic production, came to serve as a symbolic challenge to the rivals rather than a fullfledged social engineering venture.

\section{Practical Aspects}

Islamists realized that a democratic regime entailed both opportunities and constraints for its players. They praised democracy as a blessing, ${ }^{63}$ because unlike the singleparty regime, it allowed Islamists to exist and created the possibility of institutional change. However, perceiving themselves as the representatives of the truth of God, Islamists also considered the plurality of truths in democracy as inherently offensive to Islam. They felt compelled to put up with democratic plurality only because the other option would be submitting to the authoritarian RPP's truth. ${ }^{64}$

Accordingly, Islamist demands and actions were twofold. First, they sought the reversal of secular reforms, asking for the abolishment of women's rights, the sovereignty of Islamic laws, i.e. the Sharia regime ${ }^{65}$ and the reintroduction of the constitutional clause declaring Islam as the religion of the state. ${ }^{66}$ There were also symbolic radical demands ranging from the closure of Freemason associations ${ }^{67}$ to the reopening of Ayasofya (St. Sophia) Museum to daily prayers. ${ }^{68}$ Second, these contentious 
demands were almost always accompanied by milder ones aiming at changing the scope and nature of state involvement with religion. Such requests included increases in the budget and personnel of the PRA, pay raises for PRA employees, establishing more PLP schools, introducing religious classes in junior high and high schools, opening Qur'an and Arabic courses, and establishing scholarships for students of the Faculty of Theology at Ankara University. The conservative-nationalist deputies within the DP always supported these milder demands. ${ }^{69}$

As noted above, the radical claims were made in the name of the Muslim nation and complemented the above-discussed ideational products. As such, in challenging the authority of the power holders, Islamists also reproduced the doxa of the political field. The milder demands, in turn, reflected the double nature of Islamist ideational production: they aimed at increasing state investment in the religious domain, and thereby their social, symbolic, and economic capital. They were, as DP deputy Ali Fahri İseri pointed out, seeds they sowed in the public space. ${ }^{70}$ In return for the government granting the mild demands, Islamists agreed to forego the radical demands.

In the budgetary discussions of 1952, İşeri argued that one should be able to inquire into the possibility of reintroducing polygamy into the Civil Law. Met with strong negative reaction, he replied that in democracies people are considered mature (reşit) enough to express their views freely, and since the Turkish nation had proved its maturity, people should be free to discuss any subject without being labeled as a reactionary. He felt that mere discussion of such things was not harmful; it would not necessarily and immediately result in legislation. After legitimizing his demand, which targeted one of the pillars of secular reforms, İşeri immediately turned to his practical and moderate concern: airing religious speeches on the state radio station at least two or three times a week. Deputy Prime Minister Samet Ağaoğlu's response highlighted the DP leadership's attitude toward such challenges and the possibility of compromise. He declared that the government would take into consideration only those statements congruent with the DP program; other statements should not be taken seriously. He then added, amidst much applause and joy, that the government was willing to allocate an additional 480,000TL to be shared between the PRA and the employees of provincial mosques. ${ }^{71}$

\section{Conclusion}

The introduction of a multi-party regime and the ensuing liberalization in the political and religious domain resulted in the first wave of Islamist mobilization in Republican Turkey. Despite formal constraints and the lack of a political organization of exclusively their own, Islamists created networks and engaged with power holders through publications, associations, and the right-wing political parties represented in the GNA. The balance between orthodoxy and heterodoxy that the political context imposed, and that Islamists skillfully (re)produced, enabled Islamist magazines and political elites to influence the polity: not only did religious rhetoric, signs, and symbols gain unprecedented value, but state investment in the religious domain steadily increased throughout the period and in the following years. ${ }^{72}$ 
The Islamists achieved the following major short-term impacts: PLP courses that had been established by the RPP in 1949 were transformed into specialized threeyear junior high schools in 1951, with nineteen PLP schools opened by $1959 .{ }^{73}$ An Institute of Islam was established in 1959 to further train the PLP graduates. Moreover, religious education in primary schools was elevated to a quasi-compulsory status in 1951 by introducing the opt-out system, in which parents who wanted their children exempt from these courses had to submit a written request. ${ }^{74}$ In 1956, the religious classes were expanded to junior high schools. The funds allocated to state-controlled religious institutions steadily increased until the International Monetary Fund imposed austerity measures in 1959. This guaranteed maintenance of and personnel in mosques, whose construction was mostly financed by private individuals and associations established for this purpose. The increases in PRA cadres and budget extended its influence and presence in the country and created job opportunities for Islamists in local religious networks. ${ }^{75}$ Increases in the PRA's budget were also intended to elevate the standards of living of religious personnel and render a career in the PRA more attractive, thereby increasing enrolment in PLP schools.

Regarding long-term impacts, Islamists successfully introduced strong religious themes in the political field and managed to normalize a policy of public spending in (Sunni) religious affairs, which created a potential pool for future Islamist recruitment. By 1965, as the polity re-liberalized, the elites of the Islamist generation that had been formed in the 1950s were working toward the establishment of the National Order Party, the first in a series of NOM parties that have become a consistent feature of politics in Turkey. Necip Fazıl, Eşref Edip, and Süleyman Arif Emre, one of the lawyers of the NP in the party closure case, were influential actors in the party's establishment in 1970 .

\section{Notes}

1. For instance, see Toprak, Islam and Political Development in Turkey and Yavuz, Islamic Political Identity in Turkey. Earlier studies give more information on the action and interaction of Islamist actors within the political field, though they juxtapose Islamist activism with religious activity in general and religiousness with Islamism. See, for example, Lewis, "Islamic Revival in Turkey," $38-48$.

2. The entire set of cognitive and evaluative presuppositions of a given sociological field, in this case, the political field. Bourdieu, Méditations Pascaliennes, 145.

3. Islamist actors include the activists and elites of the Risale-i Nur Talebeleri (Risale-i Nur Students or the Students of Epistles of Light, 1926-present) and the Milli Görüs Hareketi (the National Outlook Movement (NOM), 1967-present). Non-Islamists are local and national elites and activists of the former DP and its successor, the Justice Party (1961-80). The interviews were conducted for Gencel Sezgin's larger PhD project on Islamist political engagement in the 1960s and 1970s. Interviewee names are not disclosed to preserve anonymity.

4. For instance, the RPP introduced elective religious classes in the primary schools, established PLP annual courses, opened the tombs and shrines of the saints and sultans to the public and allocated funds for pilgrimages to Mecca in the immediate aftermath of the transition to multi-party regime.

5. Tarrow, Power in Movement, 32-3. 
6. As sets of interpersonal relations networks provide "structural connection" and "socialization functions." They interconnect individuals, help information flow and, through prior socialization, render their members predisposed to sympathize with certain ideas and frames. Passy and Giugni, "Social Networks and Individual Perceptions: Explaining Differential Participation in Social Movements," $127-8$.

7. The RNS was organized around the persona and writings of Bediüzzaman Said Nursi (1878-1960).

8. The Süleymancı Movement was established around the persona and teachings of Süleyman Hilmi Tunahan (1888-1959) and specialized in the establishment of underground Kur'anic courses.

9. To establish the DP, its leader (Celal Bayar) had agreed (with President of the Republic, and the RPP, İsmet İnönü) to uphold the Kemalist secularism principle. In fact, the DP founders had been socialized into politics within the RPP and were no less secular than the Kemalists. The DP, therefore, not only maintained the existing formal constraints, but also expanded, or helped to expand, their scope. In 1949, with the cooperation of the DP, Article 163, prohibiting religious propaganda and activities against the secular character of the state, was expanded to target associations with similar aims. Articles 241, 242 and 529 of the Penal Code, inherited from the single party era and stipulating punishments for those who "bring the administration, laws, or executive actions of the government into disrepute, or incite disobedience" and "conduct religious celebrations and processions outside recognized places of worship" were also maintained after 1950. The DP also enacted the "Atatürk Protection Law" (Atatürk'ü Когита Капипи) in 1951 to outlaw open disrespect towards Atatürk and thus made it more difficult to criticize secular reforms. See respectively, Osman, TBMM Tutanak Dergisi, Session VIII, 680-97; Lewis, The Emergence of Modern Turkey, 412; Ahmad, The Turkish Experiment in Democracy, 1950-1975, 367.

10. For smaller parties established in alliance with the conservative nationalists see Toprak, Islam and Political Development in Turkey, 75 and Akkerman, Demokrasi ve Türkiye'de Siyasi Partiler Hakkinda Kisa Notlar, 44-64.

11. A "religious-nationalist" press flourished in all Anatolian provinces. See Brockett, How Happy to Call Oneself a Turk.

12. Islamist circles and publications refer to these editors by their first names, except for Osman Yüksel, who came to unofficially acquire the name of his publication as a second last name.

13. Interviews with a local elder of Maraş and Antep RNS branches, İstanbul, November 26, 2007, and May 15, 2008, and a Kayseri local leader and founder of the National Order and National Salvation Parties, Kayseri, September 6, 2006.

14. These sister magazines were published from the mid-1940s through the mid-1950s.

15. Interview with an ultranationalist founder and leader of the NAT's Kayseri branch, Kayseri, August 24,2006 . It should be re-emphasized that not all members of local right-wing networks, including the NAT, subscribed to the Islamist movement.

16. In three brief unsuccessful attempts in the 1950s, Büyük Doğu tried to appear as a daily as well. Uğur, Türk Basin Tarihi (1919-1989), 199. The present study focuses only on the magazines.

17. It should be added that the future activists of the Islamist NOM and the Justice and Nationalist Action Parties were reported to have read Büyük Doğu in the 1950s.

18. http://www.necipfazil.com/cemiyet.htm.

19. Karabatak, "İslâm Demokrat Partisi," 197.

20. These were the National Resurgence Party (Milli Kalkınma Partisi), the first party established following the liberalization, and the Turkish Conservative Party (Türk Muhafazakar Partisi), to which he would return following the abolition of the IDP. Karabatak, 197, 205.

21. Ibid., 199-200.

22. Among them, Kenan Öner, Osman Nuri Köni, Osman Bölükbaşı, and Marshal Fevzi Çakmak (the army's Commander in Chief during Atatürk's and İnönü's presidencies and a beloved conservativenationalist leader). Karpat, Turkey's Politics, 432.

23. For the DP congresses, see Duman, Demokrasi Sürecinde Türkiye'de Íslamcllk, 41, and Cahiers de L'Orient Contemporain, 114. For the NP congresses see for example, Ahmad and Ahmad, Türkiye'de Çok Partili Politikanın Açıklamalı Kronolojisi (1945-1971), 97. 
24. Except for Sebilürreşad, which had connections with Islamists in the NP, such as M. Raif Ogan, who frequently contributed to the magazine.

25. These two attempts were the Progressive Republican Party (Terakkiperver Cumhuriyet FurkastNovember 1924-June 25) and the Free Republican Party (Serbest Cumhuriyet Firkast- AugustNovember 1930).

26. Lewis, "Islamic Revival in Turkey," 43.

27. The above-mentioned RNS elder of Maraş and Antep, though an executive of the local NP branch, always supported and voted for the DP. He emphasized that this was a general trend among NP activists. In Kayseri, too, future activists of the NOM stated that they sympathized with, but did not vote for, the NP.

28. “Nedir Bu Adamların Din ile Zoru?” Sebilürreşad, no. 148 (April 1953), 361.

29. Çapan, "İnkılabı Bekliyoruz!" 11.

30. Edip, "Hükümetin Programı ve Ezan Meselesi," p. 66.

31. Ömer Bilen, TBMM Tutanak Dergisi, Sesion IX, 436-7.

32. Osman Köni, TBMM Tutanak Dergisi, Session VIII, 554.

33. Edip, "Laik Devletin Laik Meclisinde Din Meseleleri Konuşulamaz," 116.

34. Büyük Doğuculardan Bir Grup, "Milletçe Ağliyoruz!" 3.

35. DP Meclis Grubu Müzakere Zabıtı, (June 9, 1953), 17.

36. Reed, "Secularism and Islam in Turkish Politics," 338.

37. Karpat, Turkey's Politics: The Transition to a Multi-Party System, 434.

38. Ahmad, The Turkish Experiment in Democracy, 1950-1975, 370.

39. It has been stated that the perpetrators were members of these organizations. Cahiers de L'Orient Contemporain, 206.

40. Yüksel, "Ayasofya!" 5-7.

41. When the NP was reestablished a month later, Islamist elites were excluded. Ahmad, The Turkish Experiment in Democracy, 1950-1975, 369.

42. Regarding the expulsions see DP Meclis Grubu Müzakere Zabıtı (December 16, 1952), 1; (March 24, 1953), 1; and (February 3, 1953), 1.

43. Cited in Ahmad and Ahmad (1977), 106.

44. The Islamist deputies from Isparta were readmitted shortly before 1954 elections.

45. For the DP government's measures to silence the press, universities, unions and opposition in general see Eroğul, Demokrat Parti, Tarihi ve İdeolojisi, 189-200.

46. In social movement literature the qualities and functions attributed to collective action frames and collective identity frames greatly converge despite efforts to analytically separate them. See Benford and Snow, "Framing Processes and Social Movements: An Overview and Assessment," 611-39 and Hunt and Benford, "Collective Identity, Solidarity, and Commitment," 433-57.

47. Bourdieu, "Sur le Pouvoir Symbolique," 206. In this essay, Bourdieu focuses on the relations of power between the classes. However, he applies his conceptualization of symbolic production to any relation of power between groups who play within a given field.

48. Bourdieu, "Sur le Pouvoir Symbolique," 206-7.

49. Bourdieu, Méditations Pascaliennes, 145.

50. Bourdieu, "Le Champ Scientifique," 100. Bourdieu's analysis of the scientific field seems much more useful to understand the nature of power relations in a given field. The Turkish political field of these years witnessed the clash of the legitimacy of "the truths" (the positivist truth of the Kemalists and the religious truth of the Islamists), much like the clash of truths in a scientific field.

51. Binnaz, Islam and Political Development in Turkey, 39-40.

52. Bozarslan, "Islam, Nationalisme ou les Paradoxes Turcs," 17.

53. Bozarslan, "Islam, Laicité et la Question d'Autorité de l'Empire Ottoman à la Turquie Kemaliste," 112.

54. See also Davison, "Turkey, a "Secular" State? The Challenge of Description," 333-350.

55. Bozarslan, "Islam, Laicité et la Question d'Autorité de l'Empire Ottoman à la Turquie Kemaliste," 112.

56. Ibid. 
57. Ibid., 111.

58. See also Brockett, How Happy to Call Oneself a Turk. He argues that the provincial press reflected a nationalism infused with the religious identity of the people and produced at the local level against the secular and secularist nationalism of the state elites.

59. See, for instance, "23 Nisan ve Kuvayi Milliyeciler," Serdengeçti, no. 22 (May 1956), 3 and "Tarihi Politikaya Alet Eden Kim?” Serdengeçti, no. 12 (Nov. 1950), 7.

60. Serdengeçti, "Ey Türk Milleti," Serdengeçti, no. 25 (Sept. 1957), 1.

61. Serdengeçti, "İmansızlar Saltanatı," Serdengeçti, no. 6 (May 1949), 3; Edip, "Hükümetin Programı," 66-78; Dedektif X Bir, “Kanun,” Büyük Doğu, 3.

62. Edip, "Kuranın Siyasi ve İctimai Umdeleri," 275.

63. Edip, "Partilerin Din Siyaseti," 3.

64. See, for instance, Kısakürek, "1001 Çerçeveden: Musaviler," 2.

65. Hasan Fehmi Ustaoğlu. Ustaoğlu, TBMM Tutanak Dergisi, Session IX, 449, 487. See also Edip, Kuranın Siyasi ve İctimai Umdeleri, 275.

66. Tunaya, İslamcılık Akımı, 201.

67. TBMM Tutanak Dergisi, Session IX, 362.

68. Yüksel, "Ayasofya," 3; the İstanbul branch of the NAT voiced similar demands. See "Ayasofya Camii," 386.

69. See, for instance, TBMM Tutanak Dergisi, Session IX, 938-1001, in passim; DP Meclis Grubu Müzakere Zabitı, (May 3, 1951), 8-48.

70. TBMM Tutanak Dergisi, Session IX, 604.

71. For this paragraph see Ibid., 604-11.

72. In this essay only the gains that could be considered public and redistributed to members of religious and Islamist networks in the form of new jobs, education opportunities, or a higher standard of living are taken into consideration.

73. Çakır, Bozan and Talu, Imam Hatip Liseleri, 60. Retrieved from http://www.tesev.org.tr/UD_OBJS/ IH\%20Efsaneler-Gercekler.pdf.

74. Toprak, Islam and Political Development in Turkey, 80.

75. In 1962, two years after the coup d'état of 1960, the Minister of State responsible for public religious establishments declared that of Turkey's 60,000 religious personnel, 55,000 had no formal education. Çakır, Bozan and Talu, Imam Hatip Liseleri, 96-7. This lack of education among PRA employees supports the view that the increase in the cadres helped previously non-recognized medrese scholars and men of religion gain a certain status through employment by the state.

\section{Notes on Contributors}

Menderes Çinar is associate professor of political science at the Department of Political Science and International Relations, Başkent University, Ankara. He is a former Giorgio La Pira research fellow at the European University Institute, Florence, and a visiting scholar at Boston University, MA. His main research interests are comparative Islamism and Turkish politics. His recent publications include Türk Parlamento Tarihi: 1965-1969, (Ankara 2012), "The Electoral Success of the AKP: Cause for Hope and Despair," Insight Turkey, 13 (2011), and "Explaining the Popular Appeal and Durability of the Justice and Development Party in Turkey." In Negotiating Political Power in Turkey: Breaking up the Party, edited by E. Massicard and N. F. Watts. Abingdon, UK and New York: Routledge, 2013.

İpek Gencel Sezgin's research focuses on Islamist collective actors and political engagement patterns. Recent publications include "How Islamist parties emerge: The case of the National Order Party." In Negotiating Political Power in Turkey: Breaking up the Party, edited by E. Massicard and N. F. Watts. Abingdon, UK and New York: Routledge, 2013. 


\section{References}

Ahmad, Feroz. The Turkish Experiment in Democracy, 1950-1975. Boulder, CO: Westview Press, 1977. Ahmad, Feroz, and Bedia Turgay Ahmad. Türkiye'de Çok Partili Politikanın Açıklamalı Kronolojisi (1945-1971). Ankara: Bilgi Yayınları, 1976.

Akkerman, Naki Cevat. Demokrasi ve Türkiye'de Siyasi Partiler Hakkında Kısa Notlar. Ankara: Ulus Basimevi, 1950.

Benford, Robert D., and David A. Snow. "Framing Processes and Social Movements: An Overview and Assessment." Annual Review of Sociology 26 (Aug. 2000): 611-6399.

Binnaz, Toprak. Islam and Political Development in Turkey. Leiden: E. J. Brill, 1981.

Brockett, Gavin D. How Happy to Call Oneself a Turk: Provincial Newspapers and the Negotiation of Muslim National Identity. Austin, TX: University of Texas Press, 2011.

Bourdieu, Pierre. Méditations Pascaliennes. Paris: Éditions du Seuil, 2003.

Bourdieu, Pierre. "Sur le Pouvoir Symbolique." In Langage et Pouvoir Symbolique, 201-211. Paris: Éditions du Seuil, 2001.

Bourdieu, Pierre. "Le Champ Scientifique." Actes de Recherches en Sciences Sociales, nos. 2/3 (June 1976): 88-104.

Bozarslan, Hamit. "Islam, Nationalisme ou les Paradoxes Turcs." Après Demain, nos. 447-449 (Oct.Dec. 2002): 16-18.

Bozarslan, Hamit. "Islam, Laicité et la Question d'Autorité de l'Empire Ottoman à la Turquie Kemaliste." Archives des Sciences Sociales des Religions, no. 125 (2004): 99-113.

Büyük Doğuculardan Bir Grup. "Milletçe Ağllyoruz!” Büyük Doğu no. 1 (April 1954).

Cahiers de L'Orient Contemporain, no. 23 (1951): 114.

Cahiers de L'Orient Contemporain, no. 26 (1952): 206.

Çakır, Ruşen, İrfan Bozan, and Balkan Talu. Imam Hatip Liseleri: Efsaneler ve Gerçekler. İstanbul: TESEV Yayınları, 2004, p. 60. Retrieved from http://www.tesev.org.tr/UD_OBJS/IH\%20EfsanelerGercekler.pdf.

Çapan, Münir Süleyman. "İnkılabı Bekliyoruz!” Büyük Doğu, no. 32 (Oct. 1950).

Davison, Andrew. "Turkey, a 'Secular' State? The Challenge of Description." The South Atlantic Quarterly, 102, nos. 2-3 (Spring-Summer 2003): 333-350.

Dedektif X Bir. "Kanun.” Büyük Doğu, no. 44 (Jan. 1951).

DP Meclis Grubu Müzakere Zabıtı, (May 3, 1951).

DP Meclis Grubu Müzakere Zabit, (December 16, 1952).

DP Meclis Grubu Müzakere Zabıtı, (February 3, 1953).

DP Meclis Grubu Müzakere Zabitı, (March 24, 1953).

DP Meclis Grubu Müzakere Zabit, (June 9, 1953).

Duman, Doğan. Demokrasi Sürecinde Türkiye’de Íslamcılık. İzmir: Dokuz Eylül Üniversitesi Yayınları, 1999.

Edip, Eşref. "Hükümetin Programı ve Ezan Meselesi.” Sebilürreşad, no. 80 (June 1950).

Edip, Eşref. "Laik Devletin Laik Meclisinde Din Meseleleri Konuşulamaz.” Sebilürreşad, no. 33 (March 1949).

Edip, Eşref. "Partilerin Din Siyaseti." Sebilürreşad, no. 76 (April 1950).

Edip, Eşref. "Kuranın Siyasi ve İctimai Umdeleri.” Sebilürreşad, no. 218 (April 1956).

Eroğul, Cem. Demokrat Parti, Tarihi ve İdeolojisi. İstanbul: İmge Kitabevi, 2003.

Hunt, Scott A., and Robert D. Benford. "Collective Identity, Solidarity, and Commitment." In The Blackwell Companion to Social Movements, edited by David A. Snow, Sarah, Anne Soule, and Hanspeter Kriesi, 433-457. Malden, Oxford and Carlton: Blackwell Publishing, 2004.

Karabatak, Haluk Ö. "İslâm Demokrat Partisi." Tarih ve Toplum, no. 130 (September 1994): 196-205.

Karpat, Kemal H. Turkey's Politics: The Transition to a Multi-Party System. Princeton, NJ: Princeton University Press, 1959.

Kısakürek, Necip Fazıl. “1001 Çerçeveden: Musaviler.” Büyük Doğu, no. 7 (Dec. 1945).

Lewis, Bernard. "Islamic Revival in Turkey." International Affairs 28, no. 1 (Jan. 1952): 38-48. 
Lewis, Bernard. The Emergence of Modern Turkey. London: Oxford University Press, 1968.

“Nedir Bu Adamların Din ile Zoru?” Sebilurreşad, no. 148 (April 1953).

Passy, Florence, and Marco Giugni. "Social Networks and Individual Perceptions: Explaining Differential

Participation in Social Movements." Sociological Forum 16, no. 1 (March 2001): 123-153.

Reed, Howard A. "Secularism and Islam in Turkish Politics." Current History 32 (June 1957): 333-338.

Tarrow, Sidney. Power in Movement: Social Movements and Contentious Politics. Cambridge: Cambridge

University Press, 2011.

Tunaya, Tarık Zafer. İslamcılık Akımı. İstanbul: İstanbul Bilgi Universitesi Yayınları, 2003.

TBMM Tutanak Dergisi, Session IX, Vol. 5 (February 22, 1951).

TBMM Tutanak Dergisi, Session VIII, Vol. 24 (February 14, 1950).

TBMM Tutanak Dergisi, Session IX, Vol. 16 (April 30, 1951).

TBMM Tutanak Dergisi, Session IX, Vol. 13 (February 23, 1952).

TBMM Tutanak Dergisi, Session IX, Vol. 20 (February 25, 1951).

Uğur, M. Nuri. Türk Basın Tarihi (1919-1989). İstanbul: Gazeteciler Cemiyeti Yayınları, 1992.

Yüksel, Osman. “Ayasofya” Serdengeçti, no. 17 (Aug. 1952).

Yüksel, Osman. “Ayasofya!” Serdengeçti, no. 22 (May 1956).

Yavuz, M. Hakan. Islamic Political Identity in Turkey. Oxford: Oxford University Press, 2003. 